PART 1

Collective Ijtihād and Genomics 
Mohammed Ghaly - 9789004392137

Downloaded from Brill.com04/26/2023 02:35:47AM via free access 


\title{
Sharia Scholars and Modern Biomedical Advancements: What Role for Religious Ethics in the Genomic Era?
}

\author{
Mohammed Ghaly \\ Historical Context of Medical and Biomedical Breakthroughs: \\ What Role Would Religion Have?2
}

By the beginning of the twentieth century, it became clear that the ramifications of the breathtaking biomedical advancements and associated technologies will not remain within the confines of scientific and clinical practices. The complex questions and challenges raised by these advancements and technologies also necessitated profound ethical considerations. Various religions and philosophies addressed these questions and challenges as part of their historical role in responding to peoples' concerns and curiosities, in addition to demonstrating that they still hold influential roles in the age of modernity, with all its new challenges. By the middle of the twentieth century, the role of religious thought in the field of biomedical ethics in Western scholarship, particularly in the United States and Western Europe, started to wane. Furthermore, several scholars who specialized in religion and theology in their academic studies brushed aside religious discourse and instead, adopted a sec-

1 Professor of Islam and Biomedical Ethics, Research Center for Islamic Legislation \& Ethics (CILE), College of Islamic Studies, Hamad Bin Khalifa University, Doha, Qatar, mghaly@ hbku.edu.qa

2 This research was made possible by the NPRP grant "Indigenizing Genomics in the Gulf Region (IGGR): The Missing Islamic Bioethical Discourse”, no. NPRP8-1620-6-o57 from the Qatar National Research Fund (a member of The Qatar Foundation). The statements made herein are solely the responsibility of the author. An earlier draft of this chapter was presented at the 6th Annual International Conference of Social and Human Sciences, organized by the Arab Center for Research and Policy (March 18-20, 2017), Doha, Qatar, whose Arabic version is scheduled for publication in the Arabic journal Tabayyun.

(C) MOHAMMED GHALY, 2019 | DOI:10.1163/9789004392137_003

This is an open access chapter distributed under the terms of the prevailing CC-BY-NC License at the time of publication. 
ular one when they embarked on the field of biomedical ethics. In his study on the history of the relationship between religion and bioethics, Albert Jonsen (Professor of the History of Medical Ethics at the University of Washington) drew a comparison between what the Italian missionary Matteo Ricci did in 1582 when he crossed the Western borders traveling to the then "forbidden empire", viz. China, and what a large number of theologians did 400 years later when they decided to specialize in the field of bioethics, in the sense that they "doffed the intellectual garb of religious ethics and donned, if not the white coats of doctors, the distinctly secular mentality of modern medicine" (Jonsen 2006, 23).

In this regard, secular discourse does not necessarily clash with religion in its essence: although, it excludes any central role it may play in the common area of ethics by distinguishing between two types of morality. On the one hand, there is the "common morality", which is universal in nature and orientation and through which the public at large can be addressed. This type of morality is developed and communicated by a secular ethical discourse. On the other hand however, there is the "particular morality", which addresses specific groups of people. The ethical discourse which is premised in religious beliefs and religiously-tented terminologies falls within the category of particular morality (Beauchamp and Childress, 2013, 2-6). It should be emphasized here that religious bioethical discourse did not completely disappear from the field of bioethics in Western scholarship. For instance, various contributions coming from the three monotheistic religions, viz. Judaism, Christianity and Islam, could always find their way to the public in addition to specialized journals like The National Catholic Bioethics Quarterly. However, these contributions remained confined to the scope of ethics as practiced by certain groups of people, such as Muslims living as a religious minority in the West or the Christian Jehovah's Witnesses. This situation continued to make the impact of such contributions marginal and narrow in comparison with those inspired by secular thought.

Islamic discourse, particularly the discipline of Islamic jurisprudence (fiqh), was not detached from these historical developments. It is true that the majority of the achievements in the field of biomedical sciences occurred outside the Muslim-majority world and in a social, political and cultural environment not familiar to many contemporary Muslim jurists. However, these jurists, together with all those who believed that Islam is a religion which remains relevant for our contemporary world and not just an ancient religious tradition ${ }^{3}$,

3 It seems that the concern of proving the contemporaneity of Islam as a religious tradition was not exclusive to Sharia scholars. Some Muslim physicians also attempted to tackle these 
felt the necessity of addressing the questions and challenges triggered by the modern biomedical advancements. Unsurprisingly, there is a link between this belief and the ongoing debates at that time about the validity of Islam and its religious ethical system (Sharia) in guiding various aspects of modern life. The position of Sharia scholars and like-minded thinkers at this time was couched in the famous phrase "Sharia is valid for all times and places." ${ }^{4}$ Clearly, these scholars felt the risk of the marginalization of Sharia in the emerging field of biomedical sciences, seen as it is one of the marvelous achievements of modernity. Hence, addressing these modern questions and challenges, which subsequently came to be known as the field of "Islamic Bioethics" became an integral part of the quest to prove the contemporaneity of Islam and its possible active and impactful role in the age of modernity.

\section{Accommodating Contemporary Challenges: The Evolving Role of Physicians}

Some early signs of Sharia scholars' concerns that some may believe that Sharia and modern biomedical sciences would conflict, were expressed in shaykh Rashīd Riḍâs fatwa (d. 1935). The fatwa was issued in response to a question about the perspectives of early Muslim jurists regarding the possible maximum duration of pregnancy, as outlined in classical figh manuals, and their incompatibility with modern facts established by credible sciences such as medicine and anatomy. The Tunisian questioner raised the point made by "Frankish doctors (al-atibbä'al-ifrinj)" working in his country regarding the impossibility of the continuation of pregnancy for such long periods that could extend into years, as claimed by early jurists. The questioner added: "They excused the position of Muslim scholars in this regard [by assaying] that the science of medicine did not disclose its secrets in past times the way it does in our present time". In his response to this question, Riḍā premised his thesis

issues, as exemplified by the book written by the famous Egyptian physician 'Abd al-'Azìz Ismā'il. The first edition of this book appeared in 1939, followed by two editions in 1954 and 1959. The book's preface was written by the then Shaykh of al-Azhar Muhammad Muṣtafā al-Marāghì (d. 1945). See, Ismāî̀ (1959).

4 The objective here is not to provide a thorough investigation of the debates about this thesis and the (counter-) arguments of each party, but just to highlight the fact that there was relationship between these debates on one hand and the supposed role of Sharia in the to-beborn field of Islamic bioethics. For further information about the literature which addressed this topic in general, see for example, Ḥusayn (1999), Tirmanīnī (1977), Qaraḍāwī (1993), Ibrāhīm (2004), Zakariyyā (1986), Jābirī (1996), and 'Ashmāwī 2004. 
that the contentions of early jurists cannot be accepted at face value on the idea that adopting these classical opinions would entail dismissing what "has been established by physicians of our time, who hail from all kinds of religions and creed, despite their vast knowledge of medicine, anatomy and physiology, and their reliance on their research and trials on instruments, sensors, probes, and the X-rays which pierce through the skin and flesh, making the body transparent and exposing its interior to the naked eye, in addition to basing their knowledge on experimentation and induction, and their collaborative work, despite living in different countries, thanks to the ease in postal and telegraphic communication". At the end of the fatwa, Ridā argued that upholding such outdated contentions and neglecting the achievements of modern science could eventually result in a wide range of harms including, the attempts of non-Muslims to "defame and discredit our Sharia based on science and experimentation, not on prejudice and fanaticism, which would eventually preclude them from converting to our religion and prevent revealing its truth to those who do not know the origin of these claims within our tradition. This also entails spreading doubt among many Muslims about the truthfulness of our Sharia and its divine nature. I mean by 'many' all those who are learning medicine and are aware of, and satisfied with, the opinions adopted by today's physician and scientists about the duration of pregnancy despite knowing that these [opinions] are incompatible with what they think as the established Sharia, attested by the Qurān and the Sunna" (Riḍā, 1910).

It seems that advocating a discourse which accommodates modern biomedical sciences and thus demonstrates the contemporaneity of Sharia and its relevance to the modern age was not exclusive to those who had a reformist agenda of the so-called reformists. In fact, the advocates of such a discourse comprised a wide range of scholars coming from different backgrounds including those who had conservative inclinations. Just as an illustrative example, we refer to the fatwa issued by the prominent Najdi scholar, Shaykh 'Abd al-Raḥmān al-Sa'dì (d. 1955) on human organ transplant, which was seen by him as a groundbreaking medical intervention at this time: "Many questions are raised these days about what recently happened in modern medicine regarding the removal of part of a human body and transplanting it into another person who direly needs it". After presenting the views of the proponents and opponents on the adoption of this modern technological advancement, alSa'di expressed his support for the position of the proponents. He concluded his fatwa by emphasizing the benefits that accrue to the Islamic religion as a result of adopting this position. In this regard he said that "It is also to be noted that people should know that Islam does not stand as a barrier against genuine and preponderant benefits (mașălih). On the contrary, it adjusts to the times 
and conditions by keeping track of the comprehensive and partial benefits and interests. Atheists delude ignorant people that Islam cannot keep up with the modern developments, and this is a calumny on their part, for the Islamic religion is the quintessence of absolute good in its comprehensive and partial facets. It provides solutions for each and every problem, specific or general, and all other systems are inherently fallible". ${ }^{5}$

However, it was not easy for Sharia scholars to deal with such modern questions, since providing answers concerning biomedical matters requires understanding the precise nature of these questions and the relevant subject matters or, using jurisprudential language, "the correct perception" (tașawwur șaḥih of the issue at hand, which plays a pivotal role in the process of "verifying of the effective rationale" (tahqìq al-manăt). In this context, we come across early and important references to the significant role of physicians assisting religious scholars in developing the right perception of modern medical issues. Because of their educational background which almost exclusively consisted of religious and Sharia-related sciences, contemporary Muslim jurists could not have direct access to the right perception of these modern biomedical advancements. In the abovementioned fatwa of Rashīd Riḍa on the maximum possible duration of pregnancy, the questioner himself was aware of this complexity. He realized that the question was two-fold where juristic and medical aspects intersect with one another. He hinted that the medical aspects would be undertaken by the physician Muhammad Tawfìq Șidqī, a cherished friend of Riḍā and one of the contributors to al-Manār journal (Riḍā 1910, 900). Although Riḍa did not reveal whether he actually consulted Șidqī while drafting the fatwa, the published text suggests that part of the information comes from a physician rather than a jurist. In this context, it is also worth mentioning the contacts between Shaykh Mușțafā al-Marāghī (d. 1945), the former Shaykh of al-Azhar, and they physician 'Abd al-'Azīz Ismāîl whom Muhammad Farīd Wajdì described as "A notable authority in medicine in the Orient, and his position today in this honorable field resembles that of Ibn Sīnā and Abū Bakr al-Rāzī during the golden Arab age of science." (Ismāīl 1952, 8). Shaykh al-Marāghī wrote a preface to Ismāîl's book Al-Islām wa al-țibb al-ḥadìth (Islam and modern medicine) (Ismā'īl 1952, 5-7). The book originally appeared in the form of articles published in Al-Balägh Newspaper and subsequently in Al-Azhar Journal (Ismā̄ill 1952, 9). Al-Sa'dī also referred to this issue in his

5 Sacìi (2011, 95-100). Also, in his book on human organ transplant, Yūsuf al-Qaraḍāwī reported and endorsed the full text of the fatwa, hailing its author as a "prominent Saudi scholar from Najd who conforms to the Hanbali jurisprudential doctrine, but who enjoys broad horizons and an innovative propensity in his interpretations and fatwas." See Qaraḍāwī (2010, 61-67). 
aforementioned fatwa by saying "All issues occurring at all times, whether their overall genus or identical cases took place before, should be conceptualized in the first place, and if their essence has become known, their characteristics have been diagnosed and one has fully conceptualized them, in their essence, their premises and results, they should then be applied to scriptural texts and their overall fundamentals." Moreover, al-Sadì explained that experts in medicine have a major role to play in the conceptualization process or developing the right perception, "Whenever the highly skilled physicians unanimously agree that the organ donor will not be subjected to harm, and we realized the interest gained by others from this, [organ transplantation] becomes a genuine and pure benefit." (Sa'dī 2011, 95-97).

Such examples show that preserving Sharia's role in the modern age of biomedical breakthroughs would not have been possible, at least from the perspective of contemporary jurists, without resorting to physicians whose expertise fall outside the scope of Sharia specialists. It was also clear that modern medicine, whose religious and ethical ramifications occupied the minds of Sharia scholars, was not different from the medicine that their predecessors dealt with. Though having Greek roots, pre-modern medicine gradually became an integral part of the Arabic-Islamic civilization. Thus, this old medicine was not unfamiliar to early jurists, at least at the level of the Arabic language which was its lingua Franca. Modern medicine, however, comprises an integral part of the Western civilization, and its scientific and technical aspects cannot be grasped without studying the output of Western academies and institutions which do not use Arabic as a research language.

With time, the need to rely on physicians becoming more and more demanding, for various reasons. For instance, one can refer to the rapid and complex evolution of biomedical sciences and the rise of a large number of techniques, which posed new ethical dilemmas, such as organ transplantation, resuscitation, Assisted Reproductive Techniques (IVF), stem cell research, gene therapy, etcetera. As described by some contemporary Muslim religious scholars, these techniques used to be part of supernatural miracles in the past (Qaraḍāwī 1996, 104). On the other hand, the modern educational system fragmented these sciences into various disciplines, ${ }^{6}$ and created multiple special-

6 It seems that the complaint about the presence of a rupture between science and various specializations was not confined to Sharia scholars in the Muslim world only. This issue was addressed by a number of Western intellectuals, philosophers and also physicians, who talked about the need for the interconnectivity of sciences and humanities, or of the "two cultures", as named by the English writer C.P. Snow in his famous lecture delivered in 1955, see Ten Have 2012. 
izations and subdivisions within each discipline to the extent that it became impossible for contemporary Sharia scholars to keep track of them, not to mention to grasp their new techniques and subtleties. The inaccessibility to this type of information for Muslim religious scholars has to do, among other things, with the fact that relevant information is usually available in English only or in other languages that these scholars do not master. ${ }^{7}$ These developments necessitated further expansion of the role played by physicians in these bioethical discussions so that they can provide religious scholars with the right perception. The increasing need for a more intensive and systematic integration of the contributions made by physicians in the process of religio-ethical reasoning (ijtihād) eventually led to activation of the mechanism of collective ijtihād in the field of Islamic Bioethics by the beginning of the 1980s. Through this mechanism, the collaboration between Sharia scholars and biomedical scientists will reach new heights later. ${ }^{8}$

The mechanism of the collective ijtihād was institutionalized through the establishment of a number of religio-scientific institutions, three of which are to be singled out here because of their seminal contribution to the discourse

7 Under the title "Conditions of ijtihād," Yūsuf al-Qaraḍāwī cited the requirement of "knowledge of people and life," stating that it is a new condition which was not mentioned by scholars of the Islamic science of fundamentals in the past. He added that this is not a prerequisite for attaining the rank of $i j t i h \bar{a} d$, but it should enable $i j t i h \bar{a} d$ to be accurate and appropriate. Speaking of this requirement, he said that the mujtahid should acquire as much as possible scientific knowledge, such as biology, physics, chemistry, mathematics, and other similar subjects, because they constitute the cultural foundation necessary for every contemporary person. He also praised the experience of al-Azhar which had introduced "these sciences in the curriculum a long time ago" (Qaradawi 1996, 104). In reality, the introduction of these sciences in al-Azhar's curricula did not bring about the required integration and interconnectivity, for the student who enrolled in the Faculty of Sharia or in other legal specializations should have spent his secondary school education in the literary studies section, where the list of required subjects excludes almost any subject related to modern medical sciences. Rather, these subjects are studied by those who join the Scientific Section so that at the university the student has the right to specialize in medicine, engineering or other modern sciences. This is what we experienced as students at al-Azhar, be it at school or university level, in the 1980s and 199os, which is the period during which this book was written and published.

8 Islamic history has witnessed interactions between Islamic jurists, especially those who assumed positions in the judiciary, and those who were known back then as "experts" in different areas of knowledge, including medicine. However, these interactions were only confined to individual cases and matters that were dealt with on a case-by-case basis, and this cooperation and interaction were not institutionalized the way they are nowadays in a number of jurisprudential institutions and academies. (See Shaham 2o10, and Wiryāshī 2016). 
on Islamic Bioethics. The Islamic Organization for Medical Sciences (Al-Munazzama al-Islāmiyya li-al-Ulüm al-Tibbiyya), which was established in $\mathrm{Ku}$ wait in 1984, is one of the most prominent institutions in this regard whose activities are exclusive to addressing bioethical issues from an Islamic perspective. The IOMS collaborates with two other institutions, namely the Islamic Fiqh Academy (Al-Majma al-Fiqhī al-Islāmī), founded in 1977 and operating under the umbrella of the Muslim World League in Mecca, as well as the Jeddah-based International Islamic Fiqh Academy (Majma' al-Figh al-Islāmì alDawlī) founded in 1981 and operating under the umbrella of the Organization of Islamic Cooperation.

The thesis that Islamic Sharia is compatible with and still relevant to contemporary life and is also valid for all times and places, as mentioned earlier, lies at the heart of the work of these institutions, especially when they tackle such emerging bioethical issues. Explicit reference to the question of Sharia has been made in some of the resolutions adopted by these institutions, including the resolution of the IIFA adopted during its fifth session held in $\mathrm{Ku}-$ wait on 10-15 December, 1988. The introductory text of the resolution entitled Tațbìq ahkām al-Sharîa (The Implementation of the Rulings of the Islamic Sharia) reads as following: "Bearing in mind that the International Islamic Fiqh Academy, which emerged from the good will of the Third Islamic Conference Summit held in Mecca, in order to seek Sharia-based solutions to the problems of the Muslim nation and the organization of the lives of Muslims in conformity with the guidelines of the Islamic Sharia, as well as the removal of all obstacles to the application of God's Sharia and the establishment of all the necessary means for its implementation" (IIFA 1988, 3471).

Despite the widespread use of the mechanism of collective ijtihād since the 1980 and its output, which is generally characterized by good quality, individual ijtihäd continued to play a role in addressing these issues. Furthermore, through the papers and studies presented to the conferences organized by these figh academies and institutions, individual ijtihäd represented the foundation of the positions adopted collectively by these institutions. Some contemporary jurists also disseminated the resolutions and recommendations of these academies by incorporating them into their own writings, which sometimes included studies presented within the framework of collective ijtihäd (Quradāghī and Muhammadī 2oo6). However, these collective resolutions and recommendations, in spite of their importance and earnestness, remain within the non-binding jurisprudential opinions which do not qualify for consensus $(i j m \bar{a})$ according to the majority of scholars, though they are less prone to error in comparison with individual $i j t i h \bar{a}$. Therefore, the area of $i j t i h \bar{a} d$ 


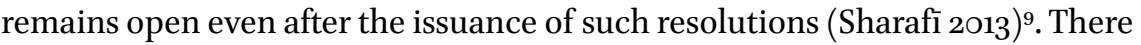
are some instances of individual ijtihäd submitted to these academies which despite not finding their way to the collective resolution, become disseminated in the form of individual opinions which may find acceptance in other contexts.

For example, the opinion of Yūsuf al-Qaraḍāwī on human milk banks was not endorsed when it was debated during the second session of the International Islamic Fiqh Academy in 1985. However, Qaraḍāwī published his opinion on this matter as part of the collection of his own fatwas, which was subsequently adopted by the European Council for Fatwa and Research during its twelfth session held in 2004 (Ghaly 2012). Finally, there are also some cases of individual ijtihād which go contrary to the resolutions and recommendations adopted by the collective ijtihäd institutions, and even call for the review of the latter. For instance, the Jordanian religious scholar, 'Abd al-Nāșir Abū al-Bașal expressed his critical comments on the resolution of the International Islamic Fiqh Academy on cloning (Abū al-Bașal 2004, 16).

\section{The Role of Sharia in the Era of Genomics ${ }^{10}$}

The early years of the twenty-first century witnessed the completion of the famous "Human Genome Project," with the United States playing an avant-garde role in it, along with several other countries. With the completion of this project, for the first time in history, the contemporary man has become able to identify himself almost entirely at the genetic level. Besides the physical structure of the human being, his organs and tissues (phenotype), human genetic structure (genotype) has been identified, and the latter constitutes the basis for the physical structure and how it functions. The human body contains

For information on some critical opinions about collective ijtihād and its contributors, see Raysūnī 2013, 64-72. Yūsuf al-Qaraḍāwī spoke in an idealistic manner, when advocating a refined collective ijtihad to be undertaken by an international Islamic scholarly academy with specific qualifications. He also stated that the agreement of this academy on a given issue which necessitates ijtihād represents "the consensus of the mujtahids of the era, claiming its own authority and becoming binding in fatwa and legislation." It is clear, however, that al-Qaraḍāwī does not mean just any of the established Islamic academies. See Qaraḍāwī 1996, 184.

Some call it the "era of genomics" given that the study of genomes has become of interest to researchers in various scientific specializations, while others opt for the term "post-genomic era" as the decoding of the genome actually paved the way for current research in the field of medical and biomedical sciences. 
nearly thirty-seven trillion cells, inside each of which-excluding red blood cells-lies DNA in the form of tightly wrapped and packed threads. Hypothetically, if the DNA threads were unwrapped and stretched out, they would span the return distance between the earth and the sun by nearly 200 times. The genome is the complete set of DNA, where DNA represents the main structure of the genome. Such a simplified image helps present the extent of the achievement of decoding the human genome, which is the sum-total of the genetic composition and includes about 30,000 genes. It is to be noted that mutations in one single gene may cause 4,00o diseases (Collins 2006, 1-2; DePamphilis and Bell 2011, 20; Lewis 2014, 1-12).

Since its inception in the last decade of the twentieth century, the Human Genome Project (HGP) has drawn significant global attention, which increased after the completion of the project and the publication of its findings in leading scientific journals. This event was compared to other major achievements in the history of science, such as the exploration of space and the discovery of nuclear fission. The HGP has equally led to major changes in the philosophy of modern medicine and its technical applications, some of which have already been used, while others are still expected. The human DNA structure has generated significant interest among biomedical scientists and physicians, and it now plays a pivotal role in various aspects of healthcare, such as in determining the appropriate diets and lifestyles for each individual, and the predictability of potential diseases even in the absence of physical symptoms. Because genetic composition varies from one individual to another, the tendency now is to embrace "personalized medicine" or "precision medicine," which stipulates that the incidence of a particular disease does not necessarily require prescribing the same type and dose of medication for all patients. Instead, these should be determined on the basis of the genetic makeup of each person. In addition, the information inscribed in the genome reveals the biological kinship of the genome bearer and his distant ancestors, which could extend to hundreds of years, and the connection to his (future) progeny. Accordingly, we often hear the phrase "book of life" in reference to the huge amount of information inherent in the human genome, which does not only relate to health and sickness, but also to human life in general (Ibn 'Abd al-Azìz 200o).

Once again, the debate about the role of Sharia in dealing with these new scientific developments resurfaced. This time, however, the historical context of the twenty-first century differed from the one that prevailed in the debate about Sharia and modern medicine by the beginning of the twentieth century. With the development of communication technologies, global distances shrunk, knowledge of scientific ventures, like the (HGP), became much more accessible, even in early stages. On the other hand, the mechanism of collec- 
tive ijtihād which brings together Muslim religious scholars and biomedical scientists became institutionalized by the beginning of the 1980 os. The abovementioned difficulties created by the type of education received by contemporary religious scholars, however, have not changed. There are even indications that these difficulties have been exacerbated, particularly with respect to the human genome. This is explicitly stated by Muhammad 'Alī al-Bār, one of the physicians known for their regular participation in, and influential contribution to, the collective ijtihäd discussions on bioethical issues. He explained these difficulties in his comments on the discussions that took place during the Symposium held by the Islamic Organization for Medical Sciences (IOMS) held in 1998, which will be outlined below. ${ }^{11}$ Thus, these developments in the genomic era have magnified the role of biomedical sciences and strengthened the need of religious scholars for biomedical scientists to explore and demonstrate the role of Sharia in this new era.

In 1993, just a few years after the official declaration of the start of the $\mathrm{Hu}-$ man Genome Project, discussions took off in the Muslim world. The Faculty of Science at the University of Qatar, in cooperation with the Islamic Educational, Scientific and Cultural Organization (ISESCO) and the World Islamic Call Society, organized a symposium under the title "Ethical Implications of Modern Researches in Genetics," which brought together religious scholars and biomedical scientists. The symposium was held on February 13-15, 1993, and issued twelve recommendations, the fifth of which was on the Human Genome Project, describing it as "the largest scientific project in the history of humanity." (İsiskū 1993, 360). These issues were also addressed by the conference on "Genetic Engineering between Shariah and Law", convened by the Faculty of Sharia and Law at the United Arab Emirates University on May 5-7, 2002. The first session of the conference was devoted to the theme "Human Genome: Its Essence and Future." The second edition was held on November 20-22, 2007 and revolved around the Sharia-based determinants (dawābit Shariyya) for

11 Al-Bār cites the book The Ethics of the Human Genome, in which the author Hānī Rizq reveals that he spent one hour explaining to jurists at this symposium the scientific aspects of the genome, but the jurists did not understand his jargon and asked for an interpretation of what he said, "because we did not understand anything at all." Al-Bār adds that although other specialists, including the late Hassān Hathūt and Al-Bār himself, tried to explain these scientific aspects more than once throughout the symposium, some of the participating jurists did not fully grasp them. (Tawșiyyāt 1998, 1112). It is worth mentioning that the published proceedings of this symposium do not include Hānī Rizq's paper, but he did present the papers written by Ṣāliḥ 'Abd al-'Azīz Karīm and Muhammad al-Yashuwī, because neither author could attend the symposium. (al-'Awaḍi and al-Jundī 2ooo, 5-10, 103, 107, 133). 
genomic research and genetic testing. Also, the Dubai-based Pan Arab Human Genetics Conference is periodically organized by the Center for Arab Genomic Studies. Moreover, in collaboration with other institutions based in Qatar, the Research Center for Islamic Legislation and Ethics (CILE) organized two activities, which focused on genomics and Islamic ethics. On October 2, 2014, a public symposium entitled "Islamic Ethics in the Era of Genomics" was organized in collaboration with the Supreme Council of Health in Qatar. Furthermore, in its session held in 2015, the World Innovation Summit for Health collaborated with CILE to organize a symposium on "Healthcare and Ethics: Genomics". A number of Sharia scholars and biomedical scientists from Qatar and abroad participated in these two symposia. ${ }^{12}$

As for the contributions of the abovementioned three key institutions, which adopted the mechanism of collective ijtihād in its institutional form, the Islamic Organization for Medical Sciences (IOMS) hosted a symposium on "Genetics, Genetic Engineering, Human Genome and Gene Therapy: An Islamic Perspective" on October 13-15, 1998 ('Awaḍi and Jundī 20oo). The final recommendations of this symposium still represent an authoritative source for most of the subsequent debates between religious scholars and biomedical scientists. In its eleventh session held on November 14-19, 1998, the International Islamic Fiqh Academy (IIFA) discussed the recommendations of this symposium, but the relevant resolution was deferred to a future session. The Islamic Fiqh Academy (IFA) also held its sixteenth session on January 5-10, 2002, which debated several issues, including the potential areas for the use of genetic fingerprinting, and issued a number of resolutions. The seventh resolution refers in passing to the human genome, emphasizing that it should not be commodified: "The human genome may not be sold to a race, to a people, or to an individual, for whatever purpose, and it may not be donated to any party, given the unethical consequences that result from these types of transactions." (IFA 2002, 360). ${ }^{13}$ Furthermore, the IOMS organized a symposium on February 6-9, 2006 entitled "Human Genetic and Reproductive Technologies: Comparing Religions and Secular Perspectives," whose recommendations included a section entitled "Declaration of Principles," citing ad verbatim segments from the recommendations adopted during the IOMS symposium held

In 2015, the Center was awarded a prestigious grant from the Qatar National Research Fund to undertake the scientific research project "Indigenizing Genomics in the Gulf Region (IGGR): The Missing Islamic Bioethical Discourse," which was officially launched by the beginning of September 2016 and would run for a period of three years. 
in 1998. Apparently, the aim here was to garner support for those principles from religious and secular voices coming from outside the Islamic discourse. (al-'Awadī and al-Jundī 2008, 1173-1175). Several years later, during its twentieth session held on September 13-18, 2012, the International Islamic Fiqh Academy (IIFA) discussed anew the recommendations of the IOMS symposium held in 1998. Once again, the resolution was deferred to a future session, yet, the participants recommended the organization of a specialized symposium to discuss these recommendations. This symposium was held in Jeddah on February $23-25,2013$ and was jointly organized by the IIFA and IOMS. Finally, during its twenty-first session held on November 18-22, 2013, the IIFA approved the resolution of the IOMS recommendations, which had been made fifteen years before, with some modifications. ${ }^{14}$ The table below provides an outline of the most important symposia and conferences which adopted the mechanism of collective ijtiha $\bar{d}$ to address the ethical issues related to genomics and associated technologies.

14 The resolution of the Academy's is entitled "Resolution on Genetics, Genetic Engineering and the Human Genome" http://www.iifa-aifi.org/2416.html (Retrieved August 4, 2017). 


\section{Chronology of Collective Ijtihād Debates on Genomics (1993-2015)}

Symposium/Conference Venue Date Organizer

\begin{tabular}{|c|c|c|c|}
\hline $\begin{array}{l}\text { Ethical Implications of Modern } \\
\text { Researches in Genetics }\end{array}$ & Doha, Qatar & $\begin{array}{l}\text { February } 13^{-} \\
15,1993\end{array}$ & $\begin{array}{l}\text { The Islamic Educational, Scientific } \\
\text { and Cultural Organization/World } \\
\text { Islamic Call Society/Faculty of Science, } \\
\text { University of Qatar }\end{array}$ \\
\hline Genetics, Genetic Engineering, & Kuwait & October $13^{-}$ & The Islamic Organization for Medical \\
\hline Human Genome and & & 15,1998 & Sciences \\
\hline
\end{tabular}

Genetic Therapy: An Islamic

Perspective

11th Session

Manama, November 14- The International Islamic Fiqh

16th Session

Bahrain

19,1998

Academy

Makkah, Saudi January 5-10, The Islamic Fiqh Academy

Arabia

2002

Genetic Engineering between

Al Ain, United

May 5-7, 2002

Faculty of Sharia and Law, United Arab

Shariah and Law

Human Genetic and

Arab Emirates

Emirates University

Cairo, Egypt

February 6-9, The Islamic Organization for Medical 2006 Sciences

Comparing Religions and

Secular Perspectives

The Ethical Perspectives of

Human Genetic Applications

Dubai, United November 20, Center for Arab Genomic Studies

Arab Emirates 2007

in the Arab World

2oth Session

Oran, Algeria September

The International Islamic Fiqh

13-18, 2012 Academy

Genetics, Genetic Engineering

Jeddah, Saudi

February 23-

The International Islamic Fiqh

and the Human Genome

Arabia

25,2013

Academy/ The Islamic Organization for

Medical Sciences

21st Session

Riyadh, Saudi

November 18- The International Islamic Fiqh

Arabia

22, 2013

Academy

Islamic Ethics in the Era of

Doha, Qatar

October 2,

Research Center for Islamic Legislation

Genomics

2014

and Ethics/ Supreme Council of

Health, Qatar

Healthcare and Ethics:

Doha, Qatar

February 17,

World Innovation Summit for Health/

Genomics

2015

Research Center for Islamic Legislation and Ethics 
It is worth noting here that approaching ethical issues from an Islamic perspective has not been limited to the institutionalized activities which adopted the mechanism of collective ijtiha $\bar{d}$. Some Muslim jurists have provided their own individual ijtiha $\bar{d}$, as reflected for instance in the writings of Nür al-Dīn al-Khādimī, a Sharia scholar who participated in the collective ijtihād activities referred to previously, e.g. the conference organized by the Faculty of Sharia and Law in 2007 and the symposium organized by the Center for Arab Genomic Studies in 2007, both held in the United Arab Emirates. Besides these participations, in his capacity as a religious scholar, Al-Khādimī, published some works that convey his individual ijtihād (Khādimī 2003 and 2004). There is also the work of the late Muhammad Ra'fat 'Uthmān (d. 2016), who participated in the conference organized by the Faculty of Sharia and Law in the UAE in 2002. Additionally, several research studies which address some of the issues related to genomics and its applications have been published, even though, to my knowledge, their authors did not participate in the discussions of collective ijtihād referred to earlier. Such studies, however, remain limited in quantity (Kan’ān 2003; Idrīs 2003; Āl Shāfi' 2007; Yashū 2015-2016; 'Ubaydī 2017).

\section{The Role of Sharia in the Genomic Era: Three Main Characteristics}

In the perception of many Muslim religious scholars and biomedical scientists, the Human Genome Project represents an important historical landmark in the development of modern science. They argued that it has provided humans with an amazing power to know themselves, especially at the molecular level, in an unprecedentedly precise and profound way. It is also, to manage diseases which used to be seen as incurable, and even to improve human physical and mental capacities. Considering the perception of religious scholars and biomedical scientists who participated in the deliberations on genomics and Islamic ethics, one can argue that the role of Sharia in the genomic era is characterized by three main points:

The first point involves demonstrating the contemporaneity of Sharia. This issue remained a recurrent point in any discussion about the role of Sharia in the discussions on genomics. The old emphasis on the ability of Sharia to deal with emerging issues of any kind is repeated while stressing that genomic technologies make no exception in this regard. In line with the aforementioned statements of Rashīd Riḍa and 'Abd al-Raḥmān al-Sacdī, Ḥasan Yashū (College of Sharia and Islamic Studies at Qatar University) in the introduction to his research on genomics, sums up the mainstream position on genomics among contemporary Muslim jurists: "Since Sharia is characterized by its transcen- 
dental and everlasting nature, it has managed through its general texts, governing principles and consistent rules, as well as by enabling flexible ijtihād, to keep abreast of all the developments and to contribute profusely to the solution of various problems, especially those related to contemporary medicine" (Yashū 2015-2016, 18).

The second point which characterized the role of Sharia in the genomic era is the adoption of a position that goes beyond what Riḍā, al-Sadī and their colleagues in the twentieth century were trying to defend. Ridāa and his like-minded religious scholars were arguing that there is no contradiction between Sharia and modern science. However, the participants in the discussions of genomics and ethics, be it at the level of collective or individual ijtihād, were not just concerned about the (im)permissibility of conducting genomic research, but mainly about how Muslims (should) contribute to this emerging field. For instance, the aforementioned symposium organized by the Faculty of Science at the University of Qatar stated "At a time when concerted efforts are being deployed by many countries to achieve the largest scientific project in the history of mankind, i.e. the comprehensive study of the complete genetic information of the entire human race and its genetic makeup known as the Human Genome Project, Muslims should not remain mere spectators who do not contribute to the study of the biological heritage of mankind and to the study of man's future. Therefore, the participants at the meeting call upon the Islamic countries that are capable of providing strong financial support commensurate with the magnitude of the project to share in this earnest human project so that we can benefit from its significant outcomes" (İsiskū 1993, 36o361). In later discussions, involvement in genomic research was seen as an act of collective duty (fard kifâya) as advocated in the final communique of the IOMS symposium held in 1998: "Given that genomic sequencing is the means to identify some genetic diseases or the susceptibility to them, it is therefore of added value to health studies and medical sciences in their endeavor to prevent or cure diseases. This makes it fall within the category of collective duties in society." (Awadì and Jundī 200o, 2, 1047-1048). The communiqué also invited the Islamic countries to embrace the field of genetic engineering by establishing research centers in this area, whose raison deetre should be in conformity with Sharia. The same position was adopted again by the International Islamic Fiqh Academy in its session held in 2013, where Muslim countries were called to join the genomic revolution..$^{15}$ This drive to encourage Muslim countries to participate in genomic research was perhaps among the factors that paved the 
way for launching national genomic projects with huge financial allocations in a number of countries led by Qatar and Saudi Arabia. The projects of these two countries were publicly announced by the end of 2013.16

The third point is the concern that genomic research and its associated technologies can result in devastating consequences especially if control is lost. Almost all religious scholars and biomedical scientists who contributed to the discussions on the interplay of genomics and Islamic ethics shared this concern, despite their differences on many other questions. They agreed that developing Shari-based determinants (dawābit Shariyya) is indispensable to make sure that genomic research and its applications will not end up deviating from the principles, ethics and provisions of Sharia. It is to be noted here that fear of ethical slippage in genomic research is not exclusive to Muslim jurists. This fear has to do with the enormous potential of genomics, which also raised concern among those in charge of the Human Genome Project (HGP) since its inception, starting from the renowned scientist and Nobel Prize laureate James Watson, who oversaw the management of the project in its early phases. Given these concerns, part of the budget of the HGP was allocated to the study of the ethical aspects of the project in the framework of the Ethical, Legal and Social Implications (ELSI) program. The ELSI program started concurrently with the scientific research in the project. This was contrary to the standard course of action in the field of biomedical ethics, where ethical issues are usually addressed after the scientific research has already taken great strides and the ethical dilemmas and challenges would emerge thereafter. In the case of genomics, however, it was clear from the onset that these dilemmas and challenges are inevitable (Green and Collins 2015). Strikingly enough, the word "religion" did not appear in this work and religious discourse was marginalized in the research output. In the program evaluation report, which assessed the first ten years of the ELSI work, this point was mentioned as part of the criticism directed to it (ELSI Research Planning and Evaluation Group 200o). This criticism caused people responsible for ELSI to become increasingly aware of the need to consider ethics-based research studies from a religious perspective. This type of research, nevertheless, remained marginal in comparison with the literature which approaches the ethical issues from a secular perspective. Undoubtedly, the marginalized position of religious discourse in this program, Innovation Summit for Health (WISH) held in Doha on November 29-30, 2016. See also Ghaly et al. (2016), 7-15. 
reflects the marginalized status of religious discourse in general in the field of biomedical ethics in the West, as noted at the beginning of this chapter.

Against this background, it was natural for the participants in the ethical deliberations in the Muslim world to have concerns about the relationship between genomics and religion and to feel the need to emphasize that genomic research should be conducted in conformity with religious principles and particularly the provisions of Sharia. Signs of this apprehensive concern were reflected in the frequent and recurrent reference to Sharia in the communiqués and recommendations of the aforementioned symposia and conferences. Just as illustrative examples, few quotations are given below from the final communiqué of the symposium organized by the IOMS in 1998 and the recommendations of IIFA in 2013. These two documents represent the essence of what collective ijtihād produced about genomics:

But the findings of this research should not automatically move to the level of practical applications before they go through the filter of Sharia-based determinants (dawäbit Shariyya). Whatever proved to be compatible with Sharia should be approved, and whatever is incompatible should not be permitted

No research shall be undertaken or treatment or diagnosis carried out in connection with a person's gene or genome unless a rigorous assessment is undertaken beforehand to gauge the potential risks and benefits associated with these activities, ensuring in the process adherence to the provisions of Sharia

No research in the human genome or any of its applications, particularly in the fields of biology, genetics and medicine, should prevail over the provisions of Sharia

Islamic countries should engage in the world of genetic engineering by establishing the relevant research centers whose raison d'être should be in conformity with the Sharia ${ }^{17}$

The genome shall not be used in a harmful way or in any form which is contrary to Sharia

17 Abdul Rahman al-Awadhi and Ahmed Rajai al-Jundi (eds.), Genetics, Genetic Engineering, Human Genome and Genetic Therapy: An Islamic Perspective, Part II, pp. 1045-1052. 
Underscoring the Sharia-based determinants (dawābit guidelines related to the human genome, as outlined in the recommendations of the symposium on Genetics, Genetic Engineering, Human Genome and Gene Therapy: An Islamic Perspective, organized by the Islamic Organization for Medical Sciences in cooperation with the International Islamic Fiqh Academy in 1998

No clinical research (clinical trials) on the human genome or any of its applications shall be conducted, particularly in the areas of biology, genetics and medicine, as long as it violates the provisions of Sharia or the human rights which is recognized by Islam ('Awaḍi and Jundī 200o, 2, 1045-1052).

The aforementioned three points, especially the third one, represent serious challenges to demarcate a role for Sharia in the age of genomics, to both Muslim religious scholars and biomedical scientists. To the same extent that genomic techniques determine the priorities and aspirations of medical and biomedical sciences in the near future, the ethical issues resulting from these techniques will likewise determine the research agendas of biomedical ethics in general. The bulk of the ethical questions posed by modern techniques, such as Assisted Reproduction Technologies (ARTs), artificial insemination, and genetic engineering, fall within the purview of the major questions raised by the field of genomics. Yet, the genomic context usually adds new dimensions and complexities to these questions. As far as the third point is concerned, a couple of studies tried to spell out the Sharia-based determinants (dawābit Shar'iyya) tailored for specific issues with relevance to genomics like medical treatment, DNA paternity, privacy and abortion (Kan'ān 2003; Khādimī 2004; Yashū 20152016; 'Ubaydī 2017). These studies filled certain gaps because the abovementioned expressions regarding the necessity of taking Sharia provisions seriously remain too general and in need of more detailed studies. This problem was highlighted by a number of Sharia scholars who argued that genomics is too complex to be governed by general and sweeping rules and standards. AlKhādimì's statement below is an illustrative example:

The human genome is not just one thing so that it can be governed by these Sharia-based determinants (dawäbit Shar iyya) in a homogenous way. Rather, it is a renewed phenomenon with its own scientific identity, characteristics, uses, outcomes, overlaps and ramifications. It also moves from one stage to another, thus increasing in complexity, fragmentation, and is multifaceted. Additionally, it is a sensitive and thorny phenome- 
non as far as it relates to human dignity and sanctity, the edifice of ethics and values, as well as the security of peoples, countries and individuals. It is first and foremost premised on certain backgrounds and intersects with specific motivations and purposes, where not only the scientific and commercial aspects overlap. But, possibly also, the doctrinal, intellectual, political, cultural and religious aspects (Khādimī 2007).

In their bid to explore the role of Sharia in addressing the ethical issues raised by genomics, the published proceedings of the abovementioned conferences and symposia and the works written by individual religious scholars have almost exclusively focused on the discipline of Islamic jurisprudence (figh). The emphasis was on highlighting specific Sharia-based determinants (dawäbit Shariyya) or juristic rulings (ahkäm fiqhiyya) which are supposed to govern specific genomics-related techniques and applications. These works depended heavily on the discipline of $f i g h$ and employed the system of "five rulings" (alahkām al-khamsa $)^{18}$ because like most pioneer studies, they were concerned with providing practical and direct answers for urgent questions. However, maintaining the role of Sharia amid the complex and multidimensional nature of the ethical questions raised by the field of genomics requires a broader and more comprehensive ethical discourse than the widely used one today, which has almost exclusively been employing the tools of figh. Below, the final section of this chapter will review the strengths of the figh-centered bioethical discourse and how its weaknesses can be improved in the future.

\section{Concluding and Critical Remarks}

This chapter surveys the deliberations, which started as early as the beginning of the twentieth-century, regarding the role of Sharia in addressing the ethical issues raised by modern biomedical sciences, including genetics and genomics. These deliberations, characterized by their almost exclusive dependence on the discipline of $f i g h$, have their own strengths and weaknesses.

With respect to the strengths, the $i j t i h \bar{a} d$ practiced by individual Muslims religious scholars, and later collectively in collaboration with biomedical scientists, in the area of biomedical ethics, significantly contributed to preserving a role for Sharia in this domain. This was different from the parallel developments in the Western bioethical discourse where the role of religion was in- 
creasingly marginalized. The most important writings and published works, in terms of quantity, quality, ${ }^{19}$ and impact in the public space ${ }^{20}$ in the Muslim world and for Muslims in general, are still based on Sharia as a source of reference. Also, contemporary Sharia scholars are still the most active contributors to these discussions within the Muslim world context. Their views and fatwas continue to be considered important references for many of the institutions operating in the field of healthcare in the Muslim world. The limited space here is not sufficient to provide all the instances which illustrate this aspect, but some illustrative examples can be mentioned. At the level of individual Muslims, the fatwas issued by some contemporary Sharia scholars testify to the existence of interaction between them and the general public, including medical doctors. For instance, 'Abd Allāh Ibn al-Ṣiddīq al-Ghumārī (d. 1992), the Moroccan jurist and Hadith scholar, responded to the questions raised by students in the Alexandria Faculty of Medicine. His answers were later published more than once (Ibn al-Ṣiddīq n.d.; idem n.d.). Also, Shaykh Jād al-Ḥaqq 'Alī Jād al-Ḥaqq (d. 1996), the former Shaykh of al-Azhar, answered a number of questions raised by female students in the Faculty of Medicine at al-Azhar University, along with some medical explanations prepared by some Faculty of Medicine professors (Jādd al-Ḥaqq 2005). Likewise, a number of fatwas on medical matters were issued by Shaykh 'Abd al-'Azīz Ibn Bāz (d. 1999) during his meetings with the staff at al-Nūr Hospital in Mecca (Ibn Bāz 1999). The final example here is Yūsuf al-Qaraḍ̄āì's published fatwas, where a separate section was dedicated to bioethical issues in the second and third volumes (Qaraḍāwī 1994, vol. 2, 525-619; Qaraḍāwī 2003, vol. 3, 513-534).

At the institutional level, various questions have been addressed to Sharia scholars by Ministries of Health and other governmental and non-governmental entities, some of which are from outside the Muslim world. ${ }^{21}$ In response

The databases which catalogue research studies on biomedical ethics in the Muslim world are a witness to this fact. An example of these is the database "Islamic Medical and Scientific Ethics," which is affiliated with one of the most important scientific research institutions in the field of biomedical ethics in the world, namely The Kennedy Institute of Ethics at Georgetown University.

This this applies to what happens within the Muslim world, such as the codification of laws that govern techniques like organ transplantation and the practices of in vitro fertilization clinics. Additionally, this holds also true for the ongoing deliberations at international forums, such as the United Nations where, for example, the fatwa issued by Ahmad al-Tayyib, the mufti of Egypt at the time, was cited in the UN discussion on cloning. (Eich 2006, 300-301, 305). 
to these questions, Muslim religious scholars issued fatwas, some of which are now published and widely circulated. Just as examples, we refer to the fatwa of Shaykh Hasan Ma'mūn (d. 1973), in response to a question from the Egyptian Al-Nūr and Amal Association, on the permissibility of donating the eye of a deceased person, and the fatwa of Shaykh Muhammad Khāṭir (d. 2004), in response to a question from the Office of the Legal Advisor to the Egyptian Minister of Health, on the use of skin from a deceased person to treat the burned skin of the living (al-Bār 1992, 327-331). The same Ministry sent another question to the Egyptian Dār al-Ifta $\bar{a}^{3}$ about the possibility of establishing a human milk bank (Jundī 1983, 458). Also, the set of fatwas issued by Shaykh al-Qaradāāì's on organ transplantation were originally responses to a list of questions from the Organization of Islamic Medicine in South Africa and the Department of Islamic Medicine at King Abdul Aziz University in Jeddah, which were compiled together and published by the Kuwait Transplant Society (Qaraḍāwī 2010 and 1996). There are also two examples from the Kingdom of Saudi Arabia, the first being the fatwa issued by the Saudi Council of Senior Religious Scholars (Hay'at Kibār al- Ulamā') in response to a question from the Head of the Pediatrics Department, Faculty of Medicine in Abha on the "procedures of cardiopulmonary resuscitation in some futile instances." The text of this fatwa was published on the website of the General Presidency of Scholarly Research and Ifta (www.alifta.net). The second example is the fatwa issued by the Permanent Committee for Scholarly Research and Issuing Fatwas (Al-Lajna al-Dā'ima li al-Buhüth al-Ilmiyya wa al-Iftä) in response to a question posed by the vice-chairman of the North West Armed Forces Hospital on the use of the defibrillator. The text of this fatwa was published on the abovementioned website as well. The hospital drafted its policies in alignment with the purport of the fatwa. ${ }^{22}$ This fatwa also became well-known among researchers who wrote on this subject in journals published in English, referring to it as Fatwa No. 12086 (Ayed and Rahmo 2014; Chamsi-Pasha and Albar 2017). Another relevant example comes from the United Arab Emirates, where a fatwa was issued in response to a question which had been occupying the minds of those working in the healthcare sector about the (in)compatibility of the "Good Samaritan"

that the former US President Bill Clinton had sent a letter to the Organization asking for the opinion of Islam on the issue of cloning in the wake of the cloning of Dolly. He also informed me that he kept the original copy of Clinton's letter at the Organization's headquarters in Kuwait. There is also the fatwa issued by the Muslim Law (Shariah) Council in the United Kingdom in 1995 on organ donation, in response to a question addressed raised by the British Department of Health (Ghaly 2012a). 
principle with Islamic Sharia. This is about individuals who volunteer to save people whose lives are in danger but do not want to be held legally accountable in case the rescue endeavor fails. The questioner also wondered whether differences in gender and religious affiliation would also matter in this case. ${ }^{23}$

The deliberations on genomics do not represent an exception to the abovesketched landscape. The aforementioned symposium organized by the Faculty of Science at the University of Qatar in 1993 adopted a position which was also held later by many who participated in the individual and collective discussions on genomics. The advocates of this position strongly called upon Muslims to contribute to this emerging scientific field. This contribution was presented as a collective duty (fard kifäya), which is incumbent on Muslims in the present era. Undoubtedly, such a positive position should have had an impact on some Muslim countries which launched national genome projects, such as Qatar and its Qatar Genome Program (QGP) and the Kingdom of Saudi Arabia which established its own Human Genome Project. Both projects were launched at the end of 2013. Qatar Biobank, which has been playing a key role in establishing and managing the QGP, paid attention from the beginning to the significance of addressing relevant ethical questions from the Sharia perspective. To do so, the Qatar Biobank convened an international symposium, which was attended by a number of Sharia scholars. In its pamphlet designed to familiarize the public with the activities of the biobank, a separate section was dedicated to the interplay of Sharia and the activities of the biobank. In this pamphlet, the biobank stressed its adherence to the "Islamic Code of Medical Ethics," also known as the "Kuwait Document," which was originally issued by the World Organization for Islamic Medicine that later became known as the Islamic Organization for Medical Sciences (IOMS). In the same pamphlet, the Qatar Biobank spoke about collaboration with the Research Center for Islamic Legislation and Ethics at Qatar Foundation (Qatar Biobank 2014, 12-13). Additionally, the biobank approached some professors in the College of Sharia and Islamic Studies at Qatar University to seek their opinion about the permissibility of using blood, urine or saliva samples for scientific research purposes, also after the death of the sample donor.

The abovementioned examples demonstrate that the efforts of Muslim religious scholars, often in collaboration with biomedical scientists, could demon-

23 See https://www.clydeco.com/insight/article/good-samaritan-principles-in-the-uae-legal-liabilities-when-administering-f (Retrieved August 16, 2017). I would like to extend here my thanks to my colleague Jothi Ravindran (Legal Adviser to the Sidra Medical and Research Center in Qatar), who drew my attention to this fatwa when she herself was seeking a fatwa from Sharia scholars in Qatar on the same subject. 
strate the relevance of Sharia to the bioethical deliberations and the ability to provide answers for the questions raised by individuals and institutions. However, keeping Sharia at the heart of bioethical discourse in the era of genomics will face challenges ahead. Below, two main important points will be highlighted to explore how certain weaknesses in the contemporary Islamic bioethical discourse can be improved. The first point is the need to revise the concept of Sharia itself and its scope. The second point concerns the pool of participants in the deliberations which theorize the presumed role of Sharia in the field of bioethics.

With respect to the challenge at the conceptual level, the term "Sharia" is one of the most frequently used words when discussing Islam, either negatively or positively, in the modern era. This holds especially true for fields like biomedical and financial ethics. Despite the frequent use of this term, rarely do we find researchers or scholars who discuss how the term Sharia should be defined or how its scope should be determined. ${ }^{24}$ However, examining available literature on biomedical ethics from an Islamic perspective, whether within the context of individual or collective $i j t i h \bar{a} d$, shows that Sharia is almost exclusively seen through the lens of Islamic jurisprudence $(f i g h)$. In other words, Sharia is perceived as a set of practical provisions to be extracted directly from the Qur'ān and Sunna or premised on the works of previous jurists throughout the history of Islam. There is no question that the juristic dimension plays a pivotal role in delineating the role of Sharia and it should not be marginalized or dispensed with. However, many of the ethical issues which arise in the genomic era do not fall within the traditional scope of the discipline of figh. The question of the genome is much more profound and complex than being merely a matter of issuing partial ethical judgements about the use of a specific form of technology in a particular context. The results of genomic research and its current and future applications raise major questions about how to (re)consider some central concepts which shaped the Islamic ethical discourse throughout history. Such as, legal capacity (taklīf), human agency, acquisition of acts (kasb), determinism and free will in the light of what genomics revealed about the role of genes in determining some aspects of our structure, tendencies, and be-

24 Some of the important exceptions in this regard include the statement made by alKhādimī in one of his research studies about Sharia guidelines for genomic research. He said that the concept of al-Shar' al-Islämī consists of two major parts: the first one manifests itself in the religious Scriptures and their detailed evidences, while the second part consists of the general rules, overall objectives, and governing principles (Khādimī 2007, 4-5). What al-Khādimā has explicitly said here indeed reflects the concept of Sharia as understood by other contemporary scholars who practice ijtihād in the field of biomedical ethics, though they might not have stated it so explicitly. 
havior, which eventually led to terms like "genetic determinism." These issues, among several others, cannot be dealt with by looking at Sharia through the lens of figh alone. Integrating insights coming from disciplines like philosophy, theology, Sufism, Qurān exegesis, and Ḥadìth commentaries are indispensable to be certain that Sharia can still continue to guide the ethical discussions of the genomic era. Therefore, the ijtihād process exploring the role of Sharia in fields like genomics should involve specialists in these disciplines and not only those specialized in figh. This leads to the second challenge which concerns the identity of the participants in the process of this ijtihad.

Throughout Islamic history, jurists have been entrusted with the task of interpreting the foundational texts of Islam (viz. Quran and Sunna) to extract practical rulings which guide the behavior of Muslims in various aspects of life including those related to states of health and sickness. This process was known as ijtih $\bar{a} d$, which literally means exerting one's utmost effort. With time, ijtiha $\bar{d}$, in its technical sense, became the monopoly of those who excel in the discipline of figh. The prominent religious scholar Muhammad al-Shawkānī (d. 1839), representing a mainstream position among Muslim jurists including the contemporary ones, argued that even if ijtihād was undertaken by specialists in other disciplines like theology, its outcome will not be recognized (Shawkānī 1999, 2, 206; Qaraḍāwī 1996, 12-13). However, the ethical questions raised by modern biomedical sciences, as explained in this chapter, revealed the inability of Muslim jurists to exercise ijtihād by themselves. This is due to various reasons, especially the educational background of these jurists which usually focused on "religious" sciences and the Arabic language. This necessitated their collaboration with biomedical scientists so they can have a proper understanding of the biomedical information related to the bioethical issues under discussion. The history of collective ijtihäd in the field of bioethics, which spans about four decades, shows the involvement of biomedical scientists in their capacity as equal "partners" in the process of $\ddot{y j t i h a} d$ with jurists, simply as "informants" whose task is limited to explaining or simplifying specific biomedical information. This position was explicitly expressed by Shaykh 'Abd al-'Azīz Ibn Bāz in his response to a question on whether patients can accept a fatwa given by a physician or if they should still consult a Sharia scholar. Ibn Bāz, said: "The patient should seek the scholars' feedback about what physicians say regarding religious rulings, because physicians are knowledgeable about their own field, and religious scholarship has its own specialists... The physician's duty is to ask but not to issue fatwas without proper knowledge, because he is not a Sharia scholar." (Ibn Bāz 1999, 24-25). The same tendency is found in the practices of figh academies. In personal communication with the Saudi physician Muhammad 'Alī al-Bār, he told me that the collective delibera- 
tions go as following: the physicians explain the scientific aspects to the jurists and together they discuss related issues. But the session dedicated to discussing and voting on the final recommendations and resolutions is attended only by the religious scholars. However, this is not a uniform practice for all institutions which employ the mechanism of collective ijtihād in the field of bioethics. The Kuwait-based Islamic Organization for Medical Sciences (IOMS) broke away from this tradition by engaging biomedical scientists in all stages, including drafting and adopting the final recommendations. Some of the religious scholars who participated in the symposia organized by the IOMS made observations about this practice. The critique was directed to the physicians who cross over the borders of their specialization and argue about religious rulings that should otherwise be left to the jurists. 'Abd al-Qādir al-'Ammārī, one of the jurists who participated in the 1983 symposium organized by the IOMS on the beginning and end of human life, said: "I call upon everyone to stick to their specialization. The physician must not deal with anything but with what he sees in front of him. Delving into the interpretation of Prophetic traditions and the discussions of the jurists should be deferred to the jurists and specialists." The late 'Isām al-Shirbīnī (d. 2010), one of the participating physicians in this symposium, commented on al-'Ammārì's position, explaining how that the process of $\ddot{j}$ tih $\bar{a} d$ should be a shared task between jurists and physicians, and that neither party can accomplish the task alone (Al-Madhkūr a.o. 1985, 221-264). Such disagreements among the participants in these collective deliberations encompass the difficulty of setting clear borders between the task of the physicians and that of religious scholars. As biomedical issues grow in complexity and ramifications, drawing a border between the task of explaining the scientific aspect of biomedical technologies, usually assigned to biomedical scientists, and addressing the ethical issues raised by these technologies, traditionally entrusted to religious scholars, is getting increasingly difficult, if not impossible in many cases. Against this background, the process of $\ddot{j} t i h \bar{a} d$ in the age of genomics requires better management and coordination between the two groups. For the group of biomedical scientists, the discussions about genetics and genomics revealed that some jurists and biomedical scientists began complaining that some of those who participated in the meetings organized by the figh academies are not coming from these scientific fields. They explain that the pool of participating biomedical scientists in the collective discussions hardly witnessed any modifications or updates since the 1980s. However, fields like genetics and genomics are relatively new and many of these scientists did not study these specializations enough. The critics argue that most of them depend only on what they read in some discrete articles but with no concrete scientific contribution to genetics or genomics. The point 
these jurists want to make is that religious scholars who participate in the collective ijtihād are usually required to produce original knowledge and not just transfer the opinions of early jurists. So, the critics argue that such requirement should also apply to the participating biomedical scientists if they want to act as partners in the process of $\ddot{j} t i h \bar{a} d$, i.e., they should also produce knowledge in fields like genetics and genomics and not just translate published material into Arabic because this would not qualify to the level of $\ddot{j} t i h \bar{a} d$, in its technical sense.

\section{References}

Abū al-Bașal, 'Abd al-Nāṣir. 2004. "Al-In'ikāsāt al-akhlāqiyya li-al-baḥth fī majāl alkhalāyā al-jidh'iyya: Ru'ya shar'iyya. Hady al-Islām, 48 (4): 11-18.

Āl Shāfi', Marī‘ ibn 'Abd Allāh. 2007. Risālat kharịtat al-jīnūm al-basharī wa-al-ithbāt al-jinā̉̇. Dirāsa ta’șilliyya tațbīqiyya. M.A. thesis Riyadh: Naif Arab University for Security Sciences.

Al-Munazzamama al-Islāmiyya li al-Tarbiya wa al-'Ulūm wa al-Thaqāfa (Īsiskū). 1993. Al-In'ikāsāt al-akhlāqiyya li al-abhāath al-mutaqddima fí 'ilm al-wirātha. Rabat, Morocco: Islamic Educational, Scientific and Cultural Organization \& Tripoli, Libya: World Islamic Call Society.

'Ashmāwī, Muḥammad Sa'īd al-. 2004. Ma'âlim al-Islām. Beirut: Mu’assasat al-Intishār al-Arabī.

'Awaḍ̄ì, 'Abd al-Raḥmān al-, and Aḥmad Rajā̄ī al-Jundī (eds.). 20oo. Al-Wirātha wa-al-handasa al-wirāthiyya wa-al-jīnūm al-basharì wa-al-'ilāj al-jīnī: Ru’ya Islāmiyya. Kuwait: Islamic Organization for Medical Sciences.

'Awaḍī, 'Abd al-Raḥmān al-, and Aḥmad Rajā'̄ì al-Jundī (eds.). 20o8. Al-Wirātha wa-altakāthur al-basharī wa in 'ikāsātuhā: Ru'yat al-adyān al-samāwiyya wa wijhat nazar al-'almāniyya. Kuwait: Islamic Organization for Medical Sciences.

Ayed, Tareq Al- and Nabil Rahmo. 2014. "Do Not Resuscitate Orders in a Saudi Paediatric Intensive Care Unit". Saudi Medical Journal. 35 (6): 561-565.

Bār, Muhammad 'Alī al. 1992. Al-Fashal al-kulawì wa-zar' al-a'c̣ā’: Al-Asbāb wa-al-a'rāạ wa-țuruq al-tashkhīṣ wa-al-iilāj. Damascus: Dār al-Qalam. Beirut: al-Dār al-Shāmiyya.

Beauchamp, Tom, and James Childress. 2013. Principles of Biomedical Ethics. Oxford: Oxford University Press, 6th ed.

Chamsi-Pasha, Hassan and Muhammad Albar. 2017. "Do Not Resuscitate, Brain Death, and Organ Transplantation: Islamic Perspective". Avicenna Journal of Medicine 7:3545 . 
Collins, Francis. 2006. The Language of God. A Scientist Presents Evidence for Belief. New York: Free Press.

DePamphilis, Melvin, and Stephen Bell. 2011. Genome Duplication. Concepts, Mechanisms, Evolution, and Disease. New York: Garland Science.

Eich, Thomas. 2006. "The Debate on Human Cloning among Muslim Religious Scholars since 1997". In Cross-Cultural Issues in Bioethics: The Example of Cloning, ed. Heiner Roetz, Amsterdam: Rodopi.

ELSI Research Planning and Evaluation Group (2000). A Review and Analysis of the Ethical, Legal, and Social Implications (ELSI) Research Programs at the National Institutes of Health and the Department of Energy. Available at http://www.genome. gov/Pages/Research/DER/ELSI/erpeg_report.pdf (Retrieved August 8, 2017).

Ghaly, Mohammed. 2012. "Milk Banks through the Lens of Muslim Scholars: One Text in Two Contexts". Bioethics 26 (2): 111-127.

Ghaly, Mohammed. 2012a. "Religio-ethical Discussions on Organ Donation Among Muslims in Europe: An Example of Transnational Islamic Bioethics". Medicine, Health Care and Philosophy 15: 207-220.

Ghaly, Mohammed. 2016. Genomics in the Gulf Region and Islamic Ethics: The Ethical Management of Incidental Findings. Doha, Qatar. based World Innovative Summit for Health (WISH). Available at http://www.wish.org.qa/wp-content/uploads/2018/o1/Islamic-Ethics-Report-EnglishFINAL.pdf, retrieved 28 May 2018.

Green, Eric, James Watson and Francis Collins. 2015. "Twenty-Five Years of Big Biology". Nature 526: 29-31.

Have, Henk ten. 2012. "Potter's Notion of Bioethics". Kennedy Institute of Ethics Journal 22 (1): 59-82.

Ḥusayn, Muhammad al-Khaḍir. 1999. Al-Sharīa al-Islāmiyya șāliḥa li kull zamān wamakān. Cairo: Nahḍat Mișr li-al-Nashr wa-al-Tawzī‘.

Ibn 'Abd al-'Azīz, Șālih. 200o. "Al-Jīnūm al-basharī... kitāb al-ḥayāt". Al-Ijjāz al-'Tlmī 7: $38-42$.

Ibn Bāz, 'Abd al-'Azīz. 1999. Fatāwā 'ājila li-mansūbī al-ṣiḥha. Al-Mamlaka al-'Arabiyya al-Sa'ūdiyya: Wizārat al-Shu'ūn al-Islāmiyya wa-al-Awqāf wa-al-Da'wa wa-al-Irshād.

Ibrāhīm, 'Abd Allāh 'Alī. 2004. Al-Sharīa wa-al-hadātha: Jadal al-aṣl wa-al-'aṣr. Cairo: Dār al-Amīn.

Idrīs, 'Abd al-Fattāḥ. 2003. "Al-Amn al-mațlūb li-'ilm-al-kharīṭa al-jīniyya". Majallat alWa y al-Islāmī 40 (450): 22-25.

International Islamic Fiqh Academy (IIFA). 1998. "Qarār tațbīq aḥkām al-Sharī́a al-Islāmiyya”. Majallat Majma 'al-Fiqh al-Islāmì al-Dawlī, 1988, 4th ed.

Islamic Fiqh Academy (IFA). 2002. A'māl wa buhūth al-dawra al-sādisa 'ashar li-al-Majma` al-Fiqhī al-Islāmī fì Makka al-mukarrama. Makka: Majma` al-Fiqh al-Islāmī.

Ismā̄ìl, 'Abd al 'Azīz. 1959. Al-Islām wa-al-țibb al-ḥadìth. Cairo: al-Sharika al-'Arabiyya li-al-Ṭibā'a wa-al-Nashr. 
Jābirī, Muhammad 'Ābid al-. (1996). Al-Dīn wa al-dawla wa taṭbīq al-Sharīa. Beirut: Markaz Dirāsāt al-Waḥda al-'Arabiyya.

Jād al-Ḥaqq, 'Alī Jād al-Ḥaqq. 2005. Aḥkām al-Sharī́a al-Islāmiyya fı masāìl țibbiyya. Cairo: Jāmi'at al-Azhar, 3rd edition.

Jonsen, Albert. 2006. “A History of Religion and Bioethics". In Guinn, David (ed.). Handbook of Bioethics and Religion, edited by David Guinn. Oxford: Oxford University Press.

Kan`ān, Aḥmad Muḥammad. 2003. "Al-Jīnūm al-basharī wa taqaniyyāt al-handasa al-wirāthiyya. Muqārabāt fiqhiyya". Majallat al-Buḥūth al-Fiqhiyya al-Mu'āṣira 15(6o): 68-101.

Khādimī, Nūr al-Dīn al-. 2003. "Al-Jīnūm al-basharī". Majallat al-Buhūth al-Fiqhiyya al-Mu'āsira, 15: 47-48.

Khādimī, Nūr al-Dīn al-. 2004. "Al-Khārița al-jīniyya al-bashariyya (al-jīnūm al-basharī): Al-Aḥkām al-Shar'iyya wa-al-ḍawābiṭ al-akhlāqiyya”, Majallat al-Mishkāt, 4(2): 5976.

Khādimī, Nūr al-Dīn al. 2007. Al-Ḍawābit al-Shariyya li-buhūth al-jīnūm al-basharī. Baḥth muqaddam ḍimna a'māl al-Mu’tamar al-'Arabī al-Thānī li-'Ulūm al-Wirātha al-Bashariyya, Dubai.

Lewis, Ricki. 2014. Human Genetics. Concepts and Applications. New York: McGraw-Hill Education, 11th edition.

Madhkūr, Khālid al-, and others (eds). 1985. Al-Hayāh al-insāniyya: Bidāyatuhā wa-nihāyatuhā min manzūur Islāmī. Kuwait: Islamic Organization for Medical Sciences.

Qaraḍāwī, Yūsuf al-. 1993. Sharīat al-Islām șāliḥa li al-taṭbìq fì kull zamān wa makān. Cairo: Dār al-Ṣaḥwa li-al-Nashr wa-al-Tawzīc .

Qaraḍāwī, Yūsuf al-. 1994. Fatāwā mu'ạșira. 2nd volume. Al-Kuwait: Dār al-Qalam. zrd edition.

Qaraḍāwī, Yūsuf al-. 1996. Al-Ijtihād fı al-Sharīa al-Islāmiyya ma'a nazarāt taḥlīliyya fì al-ijtihād al-mu'āṣir. Kuwait: Dār al-Qalam.

Qaraḍāwī, Yūsuf al-. 2003. Fatāwā mu'ạșira. 3rd volume. Kuwait: Dār al-Qalam. 3rd edition.

Qaraḍāwī, Yūsuf al-. 2010. Zirā'at al-a'ḍ̂à fì daw' al-Sharīa al-Islāmiyya. Cairo: Dār alShurūq.

Qatar Biobank. 2014. A Healthier Future Starts with You. Doha: Qatar Biobank.

Quradāghī, 'Alī, al- and 'Alī Yūsuf al-Muhammadī. (. 2006). Fiqh al-qậāyā al-țibbiyya al-mu'ạșira. Dirāsa țibbiyya fiqhiyya muqārana muzawwada bi qarārāt al-majāmic al-fighiyya wa al-nadawāt al-'ilmiyya. Beirut: Dār al-Bashāìr al-Islāmiyya. 2nd edition.

Raysūnī, Aḥmad al-. 2013. Abḥāth fi al-maydān. Manșūra: Dār al-Kalima li-al-Nashr waal-Tawzī'.

Rajā'ī al-Jundī, Aḥmad, ed. 1983. Al-Injāb fì daw’’ al-Islām. Kuwait: al-Munaẓzama al-Is- 
lāmiyya li-al-'Ulūm al-Ṭibbiyya.

Riḍā, Muḥammad Rashīd. 1910. "Muddat ḥaml al-nisā’ shar'an wa-țibban". Majallat alManār, vol. 12: 900-904.

Sa'dī, 'Abd al-Raḥmān. 2011. Majmū'mu'allafāt al-shaykh al-'allāma 'Abd al-Raḥmān ibn Nāṣir al-Sa'dī: Majmū'al-fawāid wa iqtināṣ al-awābid. Qatar: Wizārat al-Awqāf waal-Shu'ūn al-Islāmiyya.

Shaham, Ron. 2010. The Expert Witness in Islamic Courts: Medicine and Crafts in the Service of Law. Chicago: University of Chicago Press.

Sharafī, 'Abd al-Majīd al-Sūsuwwah, al-. 2013. "Ahammiyyat al-fatwā al-jamā'iyya wa-ḥujjiyyatuhā". Majallat al-Haqq 17: 22-27.

Shawkānī, Muḥammad ibn 'Alī al-. 1999. Irshād al-fuhūl ilā tạ̣qĩq al-ḥaqq min 'ilm aluṣūl. Beirut: Dār al-Kitāb al-'Arabī.

Șiddīq, Abū al-Fậl ‘Abd Allāh al-Ḥasanī al-Ghumārī, al-. N.D. Ajwiba hāmma fì al-ṭibb. Cairo: 'Alī Raḥmì.

Șiddīq, Abū al-Faḍl 'Abd Allāh al-Ḥasanī al-Ghumārī. N.D. Ta'rīf ahl al-Islām bi-anna naql al- ự̂ harām. Cairo: Dār Miṣr li-al-Ṭibāca.

Tawșiyyāt.1998. "Tawșiyyāt al-dawra al-ḥādiya 'ashara li-Majlis Majma' al-Fiqh al-Islāmī: Hawla nadwat al-Kuwayt bi-sha’n al-handasa al-wirāthiyya wa al-ilāj bi-al-jīn wa al-bașma al-wirāthiyya”. Majallat Majma' al-Fiqh al-Islāmī al-Dawlī. No. 11

Tirmanīnī, 'Abd al-Salām al-. 1977. "Wujūb taṭbīq al-Sharīa al-Islāmiyya fì kull zamān wa makān". Majallat al-Huqūq wa al-Sharīa 1(2): 181-197.

'Ubaiydī, Zaynab 'Abd al-Qādir, al-. 2017. Faḥs al-jīnūm al-basharī, Dirāsa fiqhiyya tațbiqiyya. M.A.-thesis. Doha: Qatar University.

Wiryāshī, 'Abd al-Kāfì. 2016. Irhāṣāt al-khibra al-ṭibb-shar'iyya fī al-Sharīa al-Islāmiyya. Majallat al-Huqūq 30:11-33.

Yashū, Ḥasan. 2015-2016. "Al-Jīnūm al-basharī wa aḥkāmuh fī al-fiqh al-Islāmī. Ru’ya maqāṣidiyya”. Majallat Kulliyyat al-Sharīa wa-al-Dirāsāt al-Islāmiyya, 33 (1): 17-8o.

Zakariyyā, Fu’ād. 1986. Al-Haqūqa wa-al-wahm fì al-ḥaraka al-Islāmiyya al-mu'āṣira. Cairo: Dār al-Dirāsāt wa-al-Nashr wa-al-Tawzìc. 